\title{
A NEW CHAETOGNATH, SAGITTA JOHORENSIS N. SP., FROM MALAY WATERS
}

AUTHOR(S):

Pathansali, D.; Tokioka, T.

\section{CITATION:}

Pathansali, D. ... [et al]. A NEW CHAETOGNATH, SAGITTA JOHORENSIS N. SP., FROM MALAY WATERS. PUBLICATIONS OF THE SETO MARINE BIOLOGICAL LABORATORY 1963, 11(1): 105-107

\section{ISSUE DATE:}

1963-07-20

URL:

http://hdl.handle.net/2433/175323

RIGHT: 


\title{
A NEW CHAETOGNATH, SAGITTA JOHORENSIS N. SP., FROM MALAY WATERS
}

\author{
D. PATHANSALI \\ Fisheries Laboratory, Glugor, Penang \\ and \\ T. TOKIOKA \\ Seto Marine Biological Laboratory, Sirahama, Japan \\ With Plate IV \\ While the detailed studies of the chaetognath fauna of Malay waters were \\ going on, several specimens of a strange form were collected in the Straits \\ of Johore. Superficially it resembles closely Sagitta oceanica GREY and then \\ belongs to the neglecta-group, but yet it is quite unique in having more teeth \\ in the anterior than in the posterior row. We are sure that this represents \\ Before going further to the description, the senior and junior authors wish \\ to thank the Director of Fisheries, Federation of Malaya, for his kindness in \\ allowing them to examine the material and for permission to publish this note.
} a new species and give next its full descriptions.

\section{Sagitta johorensis n. sp.}

There are eight specimens in the sample. This is a small species, nearly up to $6 \mathrm{~mm}$ in length. The length of the tail segment* varies from 29 to $33 \%$ of total length*. The body is slender, moderately opaque, and fairly rigid. The trunk is of almost uniform width throughout its length, with the constriction at the trunk-tail septum being inconspicuous. Lateral fields are not wide and body musculature is moderately developed. Head is small, neck inconspicuous, and collarette indiscernible.

Anterior fin begins at the posterior end of the ventral ganglion, not more than $1.2 \%$ of total length apart from it; it is elongate, broadest in the posterior half and completely rayed to its base; rays near the frontal end are set per-

* Total length and tail segment, in this paper, include tail fin.

Publ. Seto Mar. Biol. Lab., XI (1), 1963. (Article 6) 
pendicularly to the base of the fin. Posterior fin is as long as, or slightly longer than the anterior fin; it is broadest below the tail septum, smoothly rounded in outline, with 28 to $32 \%$ of the fin above the tail septum; rays as in anterior fin. Distance between anterior and posterior fins is rather wide, from 6 to $7 \%$ of total length. Tail fin is rather long.

The pigmented area of eye is very large, roughly roundish in outline and with a slight concavity on the outer face. Corona ciliata (fig. B) begins some distance below the eyes, and is about twice as long as the head; it has four loops, and the constrictions between loops are, on each outer margin, marked by a large sensory spot. Intestinal diverticula are very distinct.

Formulae of specimens examined:

\begin{tabular}{c|c|c|c|c}
\hline $\begin{array}{c}\text { Total length } \\
\text { in mm. }\end{array}$ & $\begin{array}{c}\text { Length of tail } \\
\text { segment as } \%\end{array}$ & Hooks & $\begin{array}{c}\text { Anterior } \\
\text { teeth }\end{array}$ & $\begin{array}{c}\text { Posterior } \\
\text { teeth }\end{array}$ \\
\hline 4.5 & 32 & $7-7$ & $13-14$ & $11-11$ \\
4.8 & 33 & $7-7$ & $14-14$ & $10-10$ \\
5.0 & 33 & $7-7$ & $13-14$ & $9-10$ \\
5.1 & 29 & $6-7$ & $15-15$ & $12-12$ \\
5.2 & 30 & $6-7$ & $13-14$ & $9-10$ \\
5.5 & 30 & $7-7$ & $13-13$ & $10-10$ \\
5.7 & 31 & $6-7$ & $12-12$ & $10-11$ \\
5.9 & 31 & $7-7$ & $14-14$ & $10-11$ \\
\hline
\end{tabular}

The anterior teeth are numerous but not stout, closely set that they overlap and may appear "fan-shaped"; the two rows of anterior teeth meet each other at an obtuse angle. Hooks are rather stout, though they diminish in thickness towards the ventral side (fig. D).

The ovary extends anteriorly beyond the posterior end of the anterior fin in mature specimens and almost reaches the anterior end of the fin at the maximum. The seminal receptacles open each on a rather prominent papilla. The seminal vesicle is situated at the caudal end of the posterior fin, and widely apart from the base of the tail fin; it is ovoid, very voluminous, and resembles superficially that of $S$. oceanica GREY. The prominent antero-lateral protuberance of the vesicle found in $S$. oceanica is absent in this species.

Remarks: This species evidently belongs to the neglecta-group and resembles superficially $S$. oceanica $\mathrm{GREY}_{\mathrm{R}}$, but differs distinctly from it in having more anterior than posterior teeth. This feature is also displayed by $S$. helenae RITTER-ZAHONY and on a form of S. hispida CoNANT, which was described by Tokioka (1959) as S. ferox f. americana. However, these two species do not belong to the neglecta-group. The characters of this species are, except for the similarity mentioned above, quite distinctive and differ from those of the above named species, $S$. helenae and $S$. hispida. It is here considered to be a 
new species to which the name Sagitta johorensis is proposed, since the species was taken in the Straits of Johore. The 5.1 and $5.7 \mathrm{~mm}$ (holotype) long specimens with the head dissected are deposited at the Seto Marine Biological Laboratory and other six specimens (paratypes, together with the $5.1 \mathrm{~mm}$ long individual) are kept at the Fisheries Laboratory, Penang.

\section{EXPLANATION OF PLATE \\ IV}

Sagitta johorensis $\mathrm{n}$. sp., the $5.7 \mathrm{~mm}$ long specimen.
A. Total animal, dorsal. $\times 23$.
B. Anterior part of body, dorsal. Enlarged.
C. Seminal vesicles, ventral. $\times 107$.
D. A hook, the third one from the dorsal side. $\times 440$.
E. Eyes. $\times 200$. 
Publ. Seto Mar. Biol. Lab., XI, 1 (1963) PLATE IV

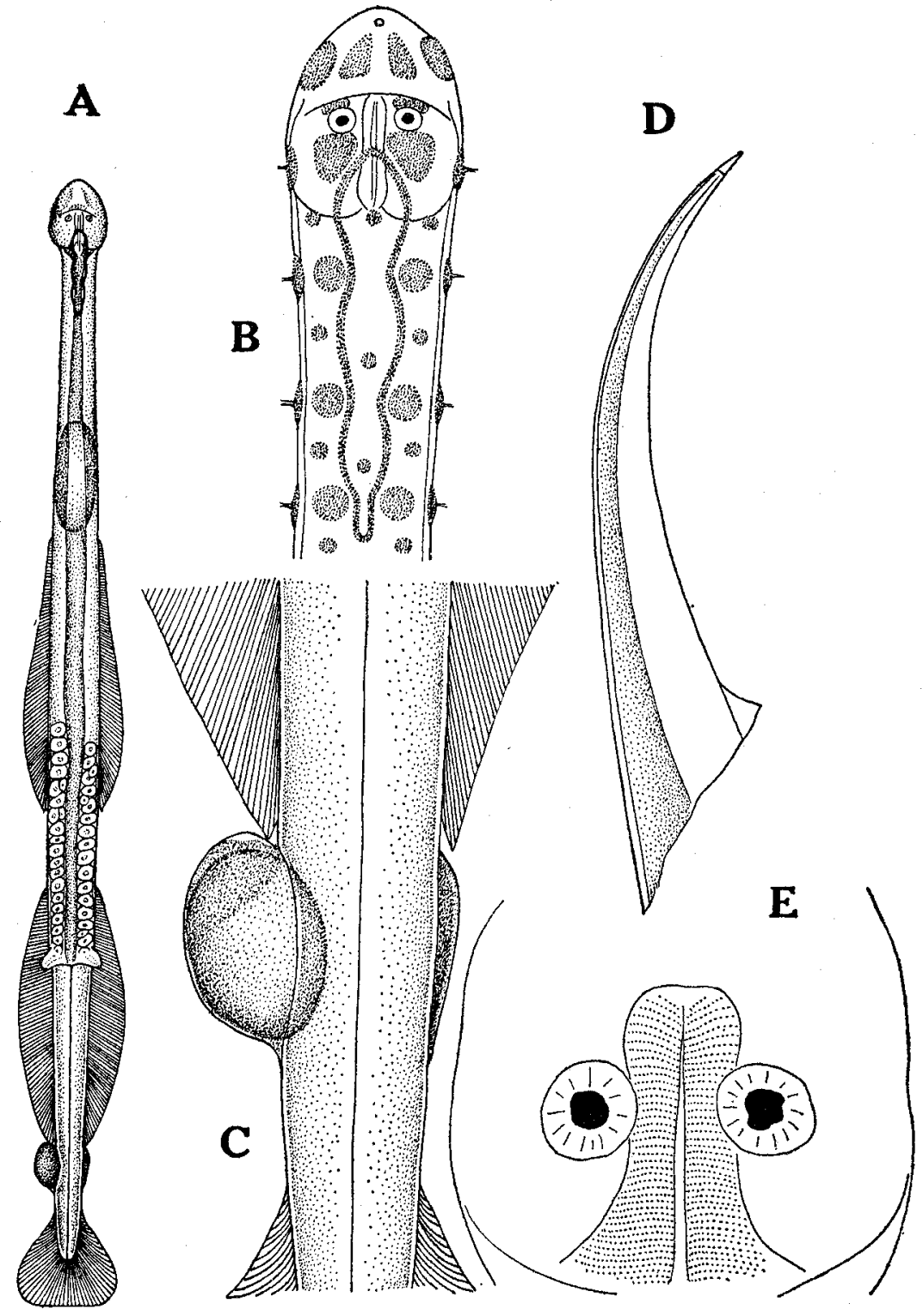

D. Pathansali and T. Tokioka; A New Chaetognath from Malay Waters. 